\title{
Effect of Amino Acid Infusion on the Ventilatory Response to Hypoxia in Protein-Deprived Neonatal Piglets
}

\author{
AMED SOLIZ, CLEIDE SUGUIHARA, JIAN HUANG, DOROTHY HEHRE, AND \\ EDUARDO BANCALARI \\ Division of Neonatology, Department of Pediatrics, University of Miami School of Medicine, \\ Miami, Florida 33101
}

\begin{abstract}
Several amino acids (AA) act as neurotransmitters and mediate the ventilatory response to carbon dioxide and hypoxia in adult human beings and animals. To evaluate the influence of $A A$ on the neonatal ventilatory response to hypoxia, 29 newborn piglets less than $5 \mathrm{~d}$ old were randomly assigned to a control diet or protein-free diet for 7-10 d. Minute ventilation, arterial blood pressure, oxygen consumption, and arterial blood gases were measured in sedated, spontaneous breathing piglets while they breathed room air and at 1,5 and $10 \mathrm{~min}$ of hypoxia (fraction of inspired oxygen concentration -0.10 ) before and after $4 \mathrm{~h}$ of AA (Trophamine, $3 \mathrm{~g} / \mathrm{kg}$, i.v.) or $10 \%$ dextrose infusion. The administration of $\mathbf{A}$ A solution in protein-deprived piglets resulted in a significant increase in minute ventilation after $10 \mathrm{~min}$ of hypoxia $(26 \pm 19 \%)$ in comparison with their ventilatory response before $\mathrm{AA}$ infusion $(10 \pm 12 \% ; p<0.02)$. Similar increase in the ventilatory response to hypoxia was observed in the control diet group after $A A$ infusion $(23 \pm 17 \%$ versus $11 \pm 11 \%$; $p<0.05$ ). Changes in arterial blood pressure, oxygen consumption, and arterial blood gases during hypoxia were similar before and after $\mathbf{A A}$ infusion. The ventilatory response to hypoxia in both protein-free and control diet animals were similar before and after the $10 \%$ dextrose infusion. These results stress the importance of nutritional factors in the neonatal control of breathing. (Pediatr Res 35: 316-320, 1994)
\end{abstract}

\section{Abbreviations}
AA, amino acids
$D_{10} W, 10 \%$ dextrose
$\mathrm{ABP}$, arterial blood pressure
BD, base deficit
GABA, $\gamma$-aminobutyric acid
$\dot{V}_{E}$, minute ventilation
$\dot{\mathrm{V}}_{2}$, oxygen consumption
VT, tidal volume

hypercarbia (1). Furthermore, these respiratory changes were reversed by the administration of enteral or parenteral protein (1-3). In preterm infants, the basal $\dot{V}_{E}$ and the ventilatory response to hypercarbia were increased after the administration of a standard AA solution (9).

The mechanisms that can explain the ventilatory changes during nutritional intervention are not fully defined. Some of these changes may be mediated by the increase and/or decrease in inhibitory or excitatory neurotransmitters in the CNS $(4,10)$. One of the latter is glutamate, a central excitatory neurotransmitter that participates in the ventilatory response to hypoxia (5). Other AA that are not neurotransmitters may also influence the central respiratory output. For example, the administration of branched-chain AA to adult human beings resulted in an increase in basal ventilation and the ventilatory response to hypercarbia $(6,7)$. Branched-chain AA may compete with tryptophan at the blood brain barrier, limiting the entry of tryptophan to the CNS and thereby decreasing the production of serotonin, which may be a respiratory inhibitor $(11-16)$. Branched-chain AA may also compete with glutamate for decarboxylation, resulting in increased glutamate levels and consequently reducing the production of GABA, which is an important respiratory depressant (17-19). Because a late ventilatory depression occurs in neonates during hypoxia (20-23) and because this depression may in part be caused by an increase in inhibitory neurotransmitters, counterbalancing their effect by dietary intervention could reverse the ventilatory depression. To our knowledge, no studies have been conducted to evaluate the influence of AA infusion on the ventilatory response to hypoxia in the neonatal period.

We hypothesized that protein deprivation during the neonatal period will decrease the ventilatory response to sustained hypoxia and that this depression can be reversed by the administration of AA. Therefore, the purpose of this study was to determine whether protein deprivation for 7 to $10 \mathrm{~d}$ decreases the ventilatory response to hypoxia in newborn piglets and to evaluate the effect of the administration of a standard AA solution (Trophamine) infusion on the ventilatory response to hypoxia in this animal model.

\section{MATERIALS AND METHODS}

Data from adult human beings and experimental animals suggest that several AA play an important role in central respiratory activity (1-8). Studies performed on adult subjects who were in a state of semistarvation demonstrated decreased basal ventilation and depressed ventilatory responses to hypoxia and

Received June 22, 1993; accepted October 4, 1993.

Correspondence: Cleide Suguihara, M.D., University of Miami School of Medicine, Department of Pediatrics (R-131), P.O. Box 016960, Miami, FL 33101.

Supported by the University of Miami School of Medicine, Project: New Born. Twenty-nine piglets less than $5 \mathrm{~d}$ of age were randomly as-
igned to either protein-free or control diet groups. The control diet consisted of $16.5 \%$ solids in solution (protein, 24\%; fat. $17 \%$; carbohydrate, $52.35 \%$ ). The protein-free diet consisted of $16.5 \%$ solids in solution (protein, $0 \%$; fat, $21.5 \%$; carbohydrate, $66 \%$ ). Both diets were prepared by ICN Biochemicals (Cleveland, $\mathrm{OH})$ and were isocaloric $(4.6 \mathrm{cal} / \mathrm{g})$. The diets were commenced at 3-5 d of age and maintained for the 7- to 10-d interval until the time of the study. 
At study, the animals were anesthetized with ketamine $(20$ $\mathrm{mg} / \mathrm{kg}$, intramuscularly) and xylazine ( $2 \mathrm{mg} / \mathrm{kg}$, intramuscularly) for surgical procedures. Lidocaine hydrochloride $(0.5 \%)$ was used for local anesthesia. The animals were lightly sedated with chloral hydrate, which was administered intraperitoneally at a dose of $100 \mathrm{mg} / \mathrm{kg}$ at intervals of 3 to $4 \mathrm{~h}$ whenever signs of arousal occurred (opening of eyes, movement of limbs or ears).

Femoral arteries and veins were cannulated and used for ABP measurements, blood gas sampling, and infusion of dextrose or AA solution. Vascular pressures were measured with pressure transducers (model P-23-ID, Gould Instruments, Cleveland, $\mathrm{OH}$ ) and recorded on a multichannel recorder (Model 3800, Gould Instruments). A tracheostomy was performed, and a $3.5-4.0 \mathrm{~mm}$ endotracheal tube was inserted.

The skin temperature was maintained at $38.5^{\circ} \mathrm{C}$ by means of a servocontrolled radiant warmer. Rectal temperature was continuously monitored with a thermistor probe (Yellow Springs Instrument Co., Yellow Springs, $\mathrm{OH}$ ). The animals received an infusion of $6 \mathrm{~mL} / \mathrm{kg} / \mathrm{h}$ of $5 \%$ dextrose solution through a peripheral vein.

Respiratory flow was measured by a heated Fleisch No. 00 pneumotachograph (OEM Medical, Richmond, VA), a differential pressure transducer (model MP45, Validyne Engineering Co., Northridge, CA), and a pressure amplifier (Gould Instruments). The flow signal was electronically integrated to obtain VT with a Gould integrator amplifier. Calibration of VT was performed before and after each study with a calibrated glass syringe. $\dot{V}_{E}$ was obtained by summation of the inspiratory volumes measured during 1-min periods of regular respiration.

$\dot{\mathrm{V}}_{2}$ was measured by the open circuit technique (24). The difference between inspiratory and expiratory oxygen concentration was measured continuously by an oxygen analyzer (model 570-A, Servomex, Crowborough, Sussex, UK) throughout the study period. $\dot{\mathrm{VO}}_{2}$ was calculated by the formula: $\dot{\mathrm{VO}}_{2}=\mathrm{VS}\left(\mathrm{FIO}_{2}\right.$ $-\mathrm{FEO}_{2}$ ), where $\mathrm{VS}$ is the flow rate through the system, $\mathrm{FlO}_{2}$ is the fraction of inspired oxygen concentration, and $\mathrm{FEO}_{2}$ is the oxygen concentration in mixed expired gas.

The animals were allowed a 2 -h stabilization period after completion of surgery. After this period, the animals were connected to a breathing circuit with a constant bias-flow of 3-4 L/ min. After $10 \mathrm{~min}$ of basal recording in room air $\dot{\mathrm{V}} \mathrm{E}, \mathrm{VT}, \dot{\mathrm{V}}_{2}$, $\mathrm{ABP}$, and arterial blood gas measurements were obtained and referred to as room air baseline. The fraction of inspired oxygen concentration was reduced to 0.10 to induce hypoxia, and after $10 \mathrm{~min}$ of hypoxia all measurements were repeated. Measurements were performed only when the animals were quiet and showing no signs of distress, as evidenced by stable heart rate and $A B P$.

After baseline hypoxia measurements were obtained, control and protein-free diet animals received $\mathrm{D}_{10} \mathrm{~W}$ or $\mathrm{AA}$ infusion (Trophamine, $3 \mathrm{~g} / \mathrm{kg}$, i.v.) for a period of $4 \mathrm{~h}$. Trophamine has the following AA composition (mg/3 g AA): isoleucine, 245; leucine, 420; lysine, 245; methionine, 100; phenylalanine, 145; threonine, 125 ; tryptophan, 60 ; valine, 235 ; cysteine, $<10$; histidine, 145; tyrosine, 70; alanine, 160; arginine, 365; proline 205; serine, 115; glycine, 110; aspartic acid, 95; glutamic acid, 150; taurine, 7. The animals were composed of the following four groups: group 1: control diet, $\mathrm{D}_{10} \mathrm{~W}$ (mean $\pm \mathrm{SD} ; n=7$; age, $12 \pm 1 \mathrm{~d}$; weight, $2879 \pm 267 \mathrm{~g}$ ); group 2: control diet, AA $(n=8$; age, $11 \pm 2 \mathrm{~d}$; weight, $2340 \pm 300 \mathrm{~g})$; group 3: proteinfree diet, $\mathrm{D}_{10} \mathrm{~W}$ ( $n=7$; age, $11 \pm 3 \mathrm{~d}$; weight, $\left.1531 \pm 386 \mathrm{~g}\right)$; and group 4: protein-free diet, AA ( $n=7$; age, $12 \pm 1 \mathrm{~d}$; weight, 1697 $\pm 396 \mathrm{~g}$ ). The volume of $\mathrm{D}_{10} \mathrm{~W}$ or AA solution was calculated to provide the same volume and calories. All the measurements were repeated at the end of the infusion period while the animals breathed room air and $10 \%$ oxygen.

Changes in cardiovascular and respiratory measurements during hypoxia were compared between dietary groups and each of the subgroups who received $D_{10} W$ or $A A$ by repeated measure analysis of variance. Paired $t$ test was used to compare the changes in ventilation with hypoxia before and after the $D_{10} W$ or $A A$ infusion.

Analysis of variance was used to compare the changes in arterial blood gases between groups. A $p<0.05$ was considered statistically significant.

Handling and care of the animals was conducted in accordance with the guidelines of the National Institutes of Health, and this study protocol was approved by the Animal Care Committee of the University of Miami School of Medicine.

\section{RESULTS}

Mean age and weights were not different between study groups before the dietary intervention. However, mean weight in protein-free diet (mean $\pm \mathrm{SD} ; n=14$; weight, $1617 \pm 383 \mathrm{~g}$ ) animals was significantly lower $(p<0.001)$ than those of control diet ( $n$ $=15$; weight, $2590 \pm 700 \mathrm{~g}$ ) animals after $7-10 \mathrm{~d}$ of dietary intervention.

Ventilatory response. The ventilatory response to hypoxia was not different between protein-free and control diet groups before the animals received the test infusions $\left(D_{10} \mathrm{~W}\right.$ or $\left.\mathrm{AA}\right)$ (Fig. 1). Although protein-free diet animals did not change their ventilatory response to hypoxia after $4 \mathrm{~h}$ of $\mathrm{D}_{10} \mathrm{~W}$ administration, a sustained increase in ventilation $(p<0.02)$ was observed after the administration of AA solution (Fig. 2). After AA infusion, a marked increase in $\dot{V} E(26 \pm 19 \%)$ was observed after 10 min of hypoxia in comparison with the ventilatory response $(12 \pm 10 \%)$ before AA. In the control diet subgroups, the ventilatory response to hypoxia was also unchanged by $D_{10} \mathrm{~W}$ infusion, whereas after $4 \mathrm{~h}$ of AA administration, VE showed a significant increase after 10 min of hypoxia $(23 \pm 17$ versus $11 \pm 11 \% ; p<0.05)$ (Fig. 3$)$. This increase in ventilation during hypoxia observed in the protein-free and control diet groups was the result of increased respiratory rate and VT (Table 1). Furthermore, the percentage increase in ventilation after $10 \mathrm{~min}$ of hypoxia was similar in both protein-free and control diet groups after AA infusion.

Cardiovascular response. Mean ABP did not differ between groups while they breathed room air or during hypoxia before drug infusions (Table 1). An increase in the ABP with hypoxia was observed in all groups independent of the type of solution administered.

Oxygen consumption and arterial blood gases. No significant differences were observed in baseline $\mathrm{V}_{2}$ or the changes in $\dot{\mathrm{V}}_{2}$ with hypoxia between protein-free and control diet groups (Table 1).

The $\mathrm{VO}_{2}$ values obtained during room air and hypoxia after AA infusion increased significantly in the protein-free diet group $(p<0.03)$ in comparison with the baseline values before AA administration.

A decrease occurred in the baseline $\mathrm{pH}$ and $\mathrm{BD}$ in the protein-

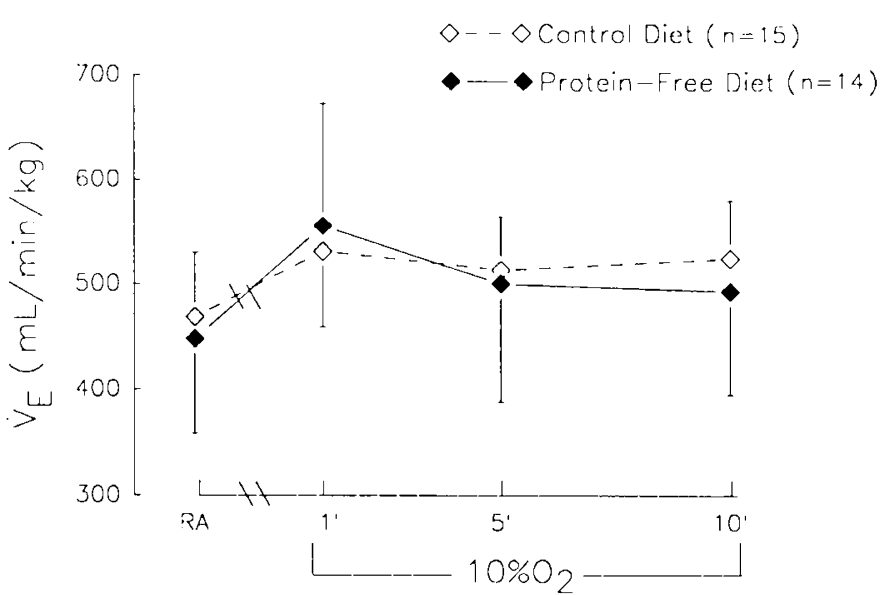

Fig. 1. Ventilatory response to hypoxia in control and protcin-free diet groups before $\mathrm{D}_{10} \mathrm{~W}$ or $\mathrm{AA}$ infusion. 

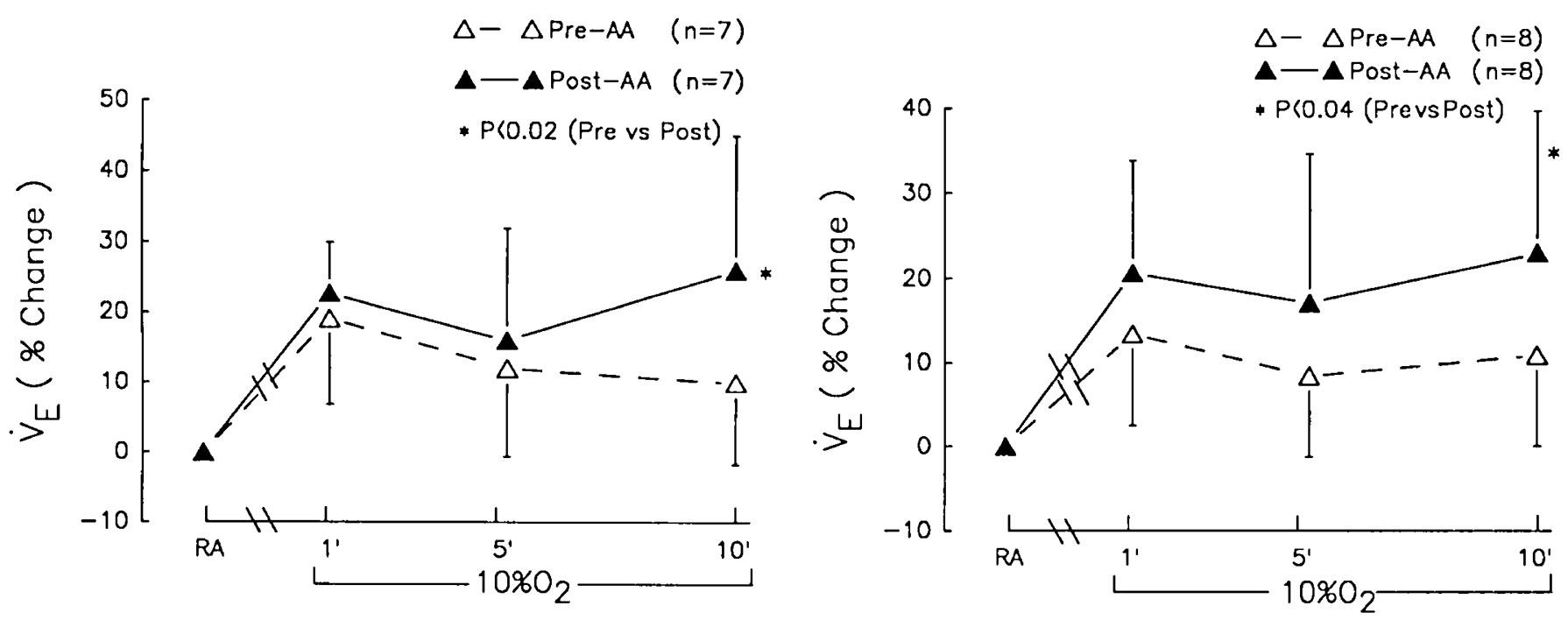

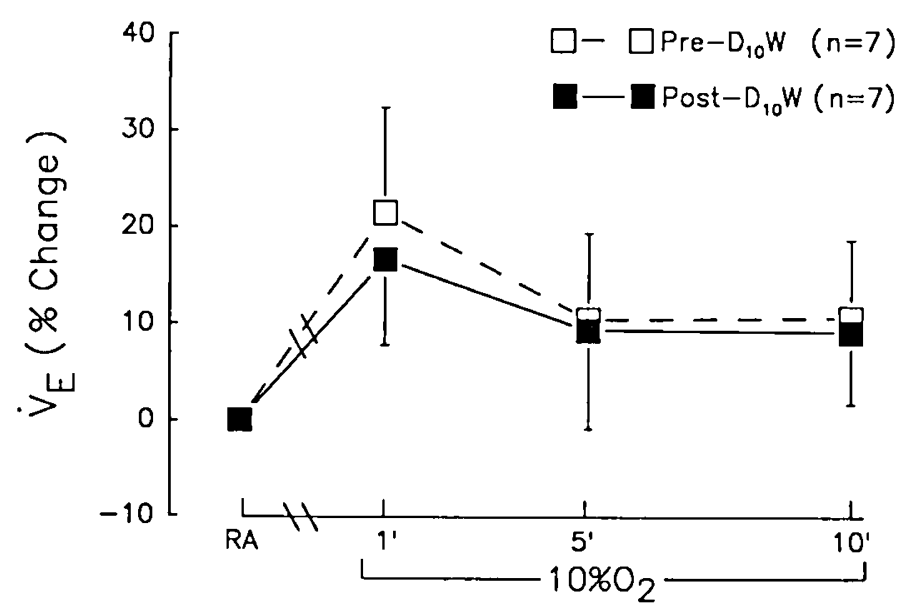

Fig. 2. Percentage change in the ventilatory response to hypoxia in protein-free diet animals before and after $D_{10} \mathrm{~W}$ or $\mathrm{AA}$ infusion.

free diet group as compared with the control diet group. However, the changes in $\mathrm{pH}$ and $\mathrm{BD}$ with hypoxia were similar in the protein-free and control diet animals. $\mathrm{PaO}_{2}$ and $\mathrm{PaCO}_{2}$ values were similar during normoxia and hypoxia in all groups (Table 2).

\section{DISCUSSION}

These results demonstrate that protein deprivation for a period of 7-10 d does not alter the ventilatory response to sustained hypoxia in neonatal piglets. Administration of a standard AA solution resulted in a sustained increase in ventilation during hypoxia in both protein-free and control diet groups.

The increase in ventilation during sustained hypoxia after $4 \mathrm{~h}$ of AA infusion was similar to the observation in semistarved adult human beings after protein intake $(1-3)$. Although the exact mechanism for sustained increase in the ventilatory response to hypoxia after AA infusion is not known, it is likely that the $\mathrm{AA}$ administration altered the balance between the excitatory and inhibitory AA neurotransmitters in the CNS (4). Preliminary results from our laboratory showed that glutamate is in part responsible for the increase in ventilation during hypoxia in unanesthetized piglets (25), whereas GABA modulates the hypoxic ventilatory depression in sedated newborn piglets (26). Administration of a standard AA solution increases branched-chain AA levels in plasma, which could increase CNS

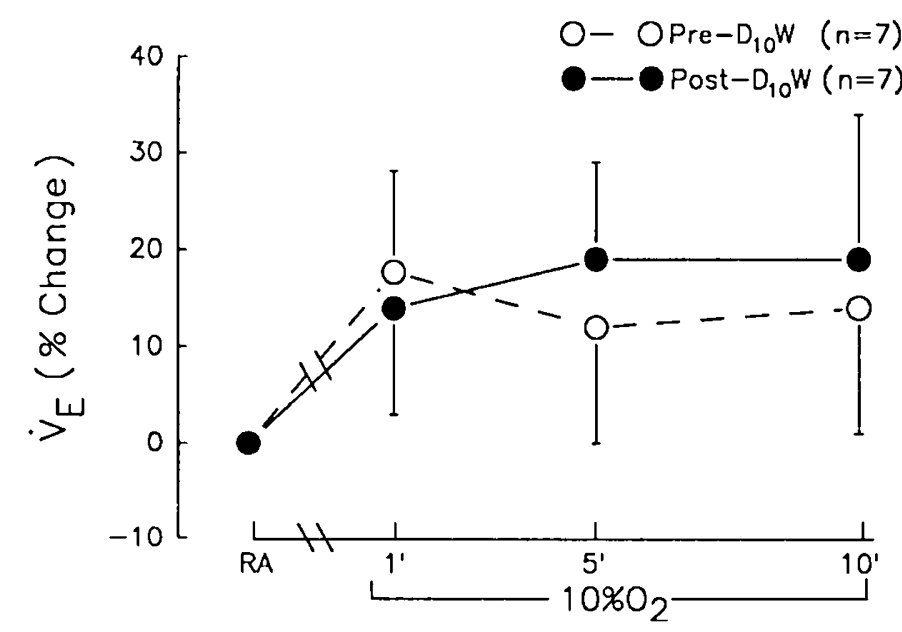

Fig. 3. Percentage change in the ventilatory response to hypoxia in the control diet animals before and after $\mathrm{D}_{10} \mathrm{~W}$ or $\mathrm{AA}$ infusion.

glutamate concentration and decrease GABA levels by competitive action with glutamate decarboxylase (17). It has also been suggested that the increased branched-chain plasma AA levels $(11,12)$ may limit the entrance of tryptophan, a precursor of serotonin that may be a respiratory depressant, (13-16) into the CNS. However, several in vivo animal studies have provided conflicting results, some showing an excitatory effect of serotonin on the central respiratory system and others demonstrating an inhibitory effect $(15,16,27-29)$. The AA solution used in this study contained proportionally more excitatory AA such as glutamate and aspartate than inhibitory $\mathrm{AA}$ such as glycine, which may also have an influence on the ventilatory response to hypoxia $(5,30,31)$. Furthermore, the fact that this AA solution does not contain GABA, an important inhibitory neurotransmitter, may facilitate the effects of excitatory AA on the central respiratory system. Further studies are needed to explain the mechanisms involved in the increased ventilatory response to hypoxia induced by the administration of AA solution.

The fact that the changes in ventilation at $1 \mathrm{~min}$ of hypoxia were not different after AA infusion as compared with before AA infusion in both groups suggests that the sustained increase in $\dot{V}_{\mathrm{E}}$ after $\mathrm{AA}$ is mediated centrally and not through a change in the activity of the carotid bodies.

Although the data support the hypothesis that AA play an important role in central respiratory output, we cannot exclude the possibility that these changes are in part related to an im- 
Table 1. Change's in $\dot{V} E_{1} V_{T} T_{1}$ respiratory rate, $\dot{V}_{2}$, and mean ABP in control and protein-free diet groups*

\begin{tabular}{|c|c|c|c|c|c|c|c|c|}
\hline & \multicolumn{4}{|c|}{$\mathrm{D}_{10} \mathrm{~W}$} & \multicolumn{4}{|c|}{ AA } \\
\hline & \multicolumn{2}{|c|}{ Pre } & \multicolumn{2}{|c|}{ Post } & \multicolumn{2}{|c|}{ Pre } & \multicolumn{2}{|c|}{ Post } \\
\hline & $\mathrm{RA}$ & $10 \% \mathrm{O}_{2}$ & RA & $10 \% \mathrm{O}_{2}$ & $\mathrm{RA}$ & $10 \% \mathrm{O}_{2}$ & RA & $10 \% \mathrm{O}_{2}$ \\
\hline \multicolumn{9}{|l|}{ Control diet } \\
\hline$\dot{\mathrm{V}}_{\mathrm{E}}(\mathrm{mL} / \mathrm{min} / \mathrm{kg})$ & $446 \pm 74$ & $507 \pm 75$ & $406 \pm 104$ & $490 \pm 98$ & $490 \pm 42$ & $540 \pm 29$ & $469 \pm 70$ & $572 \pm 86$ \\
\hline VT $(\mathrm{mL} / \mathrm{kg})$ & $7.0 \pm 0.8$ & $7.6 \pm 0.7$ & $8.2 \pm 1.8$ & $8.5 \pm 1.6$ & $7.6 \pm 1.5$ & $8.0 \pm 1.4$ & $8.7 \pm 2.0$ & $9.5 \pm 1.8$ \\
\hline RR (breaths/min) & $64 \pm 10$ & $67 \pm 10$ & $53 \pm 21$ & $60 \pm 19$ & $68 \pm 19$ & $70 \pm 16$ & $56 \pm 15$ & $62 \pm 16$ \\
\hline$\dot{\mathrm{V}}_{2}(\mathrm{~mL} / \mathrm{min} / \mathrm{kg})$ & $9.7 \pm 1.0$ & $9.3 \pm 0.8$ & $10.0 \pm 0.8$ & $9.4 \pm 1.3$ & $10.3 \pm 1.1$ & $10.1 \pm 0.9$ & $11.6 \pm 0.4$ & $11.0 \pm 1.0 \dagger$ \\
\hline Mean ABP $(\mathrm{mm} \mathrm{Hg})$ & $55 \pm 8$ & $62 \pm 13$ & $48 \pm 6$ & $53 \pm 7$ & $55 \pm 8$ & $60 \pm 10$ & $45 \pm 8$ & $47 \pm 12$ \\
\hline \multicolumn{9}{|l|}{ Protein-free diet } \\
\hline$\dot{V}_{E}(\mathrm{~mL} / \mathrm{min} / \mathrm{kg})$ & $467 \pm 110$ & $513 \pm 105$ & $444 \pm 104$ & $475 \pm 118$ & $429 \pm 67$ & $473 \pm 94$ & $445 \pm 82$ & $559 \pm 132$ \\
\hline $\mathrm{VT}_{\mathrm{T}}(\mathrm{mL} / \mathrm{kg})$ & $5.9 \pm 0.8$ & $5.9 \pm 1.0$ & $6.7 \pm 1.3$ & $7.0 \pm 1.3$ & $7.0 \pm 1.2$ & $7.1 \pm 1.3$ & $8.0 \pm 1.2$ & $8.7 \pm 1.2$ \\
\hline RR (breaths/min) & $77 \pm 11$ & $86 \pm 14$ & $66 \pm 12$ & $68 \pm 15$ & $64 \pm 13$ & $68 \pm 13$ & $56 \pm 7$ & $62 \pm 11$ \\
\hline$\dot{\mathrm{V}}_{2}(\mathrm{~mL} / \mathrm{min} / \mathrm{kg})$ & $6.7 \pm 0.4$ & $6.4 \pm 0.5$ & $6.5 \pm 0.8$ & $6.5 \pm 0.6$ & $7.3 \pm 0.9$ & $7.3 \pm 0.9$ & $8.6 \pm 0.8 \ddagger$ & $8.4 \pm 0.7 \ddagger$ \\
\hline Mean $\mathrm{ABP}(\mathrm{mm} \mathrm{Hg})$ & $52 \pm 8$ & $54 \pm 9$ & $39 \pm 8$ & $40 \pm 11$ & $57 \pm 17$ & $58 \pm 14$ & $38 \pm 8$ & $46 \pm 6$ \\
\hline
\end{tabular}

* RA, room air; $R R$, respiratory rate.

$+p<0.05$ (control diet, Pre-AA is Post-AA).

$\ddagger p<0.03$ (protein-free diet, Pre-AA is Post-AA).

Table 2. Changes in arterial blood gases and acid-base balance in control and protein-free diet group.s*

\begin{tabular}{|c|c|c|c|c|c|c|c|c|}
\hline & \multicolumn{4}{|c|}{$\mathrm{D}_{10} \mathrm{~W}$} & \multicolumn{4}{|c|}{ AA } \\
\hline & \multicolumn{2}{|c|}{ Pre } & \multicolumn{2}{|c|}{ Post } & \multicolumn{2}{|c|}{ Pre } & \multicolumn{2}{|c|}{ Post } \\
\hline & RA & $10 \% \mathrm{O}_{2}$ & RA & $10 \% \mathrm{O}_{2}$ & $\mathrm{RA}$ & $10 \% \mathrm{O}_{2}$ & $\mathrm{RA}$ & $10 \% \mathrm{O}_{2}$ \\
\hline \multicolumn{9}{|l|}{ Control diet } \\
\hline $\mathrm{pH}$ & $7.41 \pm 0.04$ & $7.41 \pm 0.10$ & $7.40 \pm 0.06$ & $7.40 \pm 0.06$ & $7.39 \pm 0.07$ & $7.40 \pm 0.06$ & $7.34 \pm 0.06$ & $7.35 \pm 0.09$ \\
\hline $\mathrm{PaO}_{2}(\mathrm{kPa})$ & $12.2 \pm 1.6$ & $4.1 \pm 0.4$ & $12.2 \pm 1.6$ & $4.2 \pm 0.3$ & $12.9 \pm 1.8$ & $4.2 \pm 0.4$ & $12.3 \pm 1.0$ & $4.5 \pm 0.5$ \\
\hline $\mathrm{PaCO}_{2}(\mathrm{kPa})$ & $4.6 \pm 0.4$ & $4.3 \pm 0.4$ & $4.5 \pm 0.3$ & $4.2 \pm 0.3$ & $4.4 \pm 0.4$ & $4.2 \pm 0.6$ & $4.2 \pm 0.5$ & $3.8 \pm 0.5$ \\
\hline $\mathrm{BD}(\mathrm{mEq} / \mathrm{L})$ & $-0.8 \pm 3.2$ & $-1.1 \pm 2.8$ & $-2.1 \pm 3.6$ & $-3.2 \pm 3.9$ & $-2.8 \pm 4.3$ & $-4.3 \pm 4.5$ & $-6.5 \pm 3.2$ & $-7.7 \pm 4.8$ \\
\hline \multicolumn{9}{|l|}{ Protein-free diet } \\
\hline $\mathrm{pH}$ & $7.35 \pm 0.06$ & $7.36 \pm 0.04$ & $7.33 \pm 0.06$ & $7.32 \pm 0.06$ & $7.36 \pm 0.09$ & $7.37 \pm 0.06$ & $7.29 \pm 0.07$ & $7.31 \pm 0.09$ \\
\hline $\mathrm{PaO}_{2}(\mathrm{kPa})$ & $13.1 \pm 1.0$ & $4.6 \pm 0.8$ & $13.9 \pm 1.3$ & $4.5 \pm 0.9$ & $14.1 \pm 1.0$ & $5.0 \pm 0.5$ & $13.6 \pm 1.4$ & $4.7 \pm 0.4$ \\
\hline $\mathrm{PaCO}_{2}(\mathrm{kPa})$ & $4.3 \pm 0.5$ & $4.3 \pm 0.6$ & $3.8 \pm 0.9$ & $3.7 \pm 0.8$ & $4.1 \pm 0.2$ & $3.8 \pm 0.4$ & $3.8 \pm 0.5$ & $3.4 \pm 0.6$ \\
\hline $\mathrm{BD}(\mathrm{mEq} / \mathrm{L})$ & $-5.7 \pm 4.4$ & $-5.4 \pm 4.2$ & $-8.7 \pm 4.0$ & $-9.2 \pm 4.3$ & $-6.3 \pm 2.9$ & $-6.4 \pm 4.6$ & $-11.1 \pm 2.6$ & $-11.3 \pm 3.5$ \\
\hline
\end{tabular}

* RA, room air.

provement in respiratory muscle function after the administration of AA.

A close relationship has been observed between the metabolic rate and ventilation (32). In addition, it has been shown that in adult human beings a significant increase in metabolic rate and ventilation occurs after $A A$ infusion (2), but this increase in ventilation exceeds the increase in metabolic rate. This finding suggests that $\mathrm{AA}$ infusion stimulates ventilation not only by increasing metabolic rate but also by specifically increasing ventilatory drive (8). In the present study, the metabolic rate decreased during hypoxia by $2 \%$ in the protein-free diet group and by $5 \%$ in the control diet animals, whereas $\dot{V}_{E}$ increased by $26 \%$ and $23 \%$ after AA infusion in the protein-free and control diet animals, respectively. Therefore, the increase in ventilation during hypoxia was independent of changes in the metabolic rate.

Changes in ABP with hypoxia among the different groups of animals were similar after the infusion of the respective solutions. Therefore, the sustained ventilatory response to hypoxia observed after AA administration cannot be explained by cardiovascular changes.

Protein-deprived animals showed a decrease in the baseline $\mathrm{pH}$ and BD. Although we do not have a clear explanation for the metabolic acidosis, this condition could result from diarrhea observed in malnourished newborn piglets. Malnutrition in newborn animals can alter gastrointestinal function $(33,34)$, and this alteration could lead to diarrhea and metabolic acidosis. After the administration of the test solutions, the BD was more pronounced in the animals that received $A A$, which could have influenced the ventilatory response to hypoxia (35). However, this is unlikely because the changes in $\mathrm{pH}$ and $\mathrm{BD}$ during hypoxia were similar in both protein-free diet groups after $\mathrm{D}_{10} \mathrm{~W}$ or $\mathrm{AA}$ infusion.

In summary, this study has shown that protein deprivation for a period of 7-10 d does not alter significantly the ventilatory response to sustained hypoxia in newborn piglets. Furthermore, the administration of a standard AA solution to newborn piglets, independent of dietary intervention, resulted in sustained increase in the ventilatory response to hypoxia, and this effect cannot be explained by changes in cardiovascular function, acidbase balance, or metabolic rate. This study also suggests that the effect of $\mathrm{AA}$ infusion on the respiratory control is centrally mediated.

The clinical implication of these results is that AA infusion to preterm infants may influence their respiratory center output. Future studies need to address the influence of specific $A A$ on respiratory control mechanisms.

Acknowledgments. The authors thank Dr. Ricardo Uauy for his encouragement and suggestions in the planning of this study and Dr. Shahnaz Duara for her critical review of this manuscript.

\section{REFERENCES}

1. Dockel Jr RC, Zwillich CW, Scoggin CH, Kryger M, Weil JV 1976 Clinical semi-starvation: depression of hypoxic ventilatory response. N Engl J Med 295:358-361

2. Weissman C, Askanazi J, Rosenbaum S, Hyman A, Milic-Emili J, Kinney JM 1983 Amino acids and respiration. Ann Intern Med 98:41-44

3. Astanazi J, Weissman C, LaSala PA. Milic-Emili J, Kinney JM 1984 Effect of protein intake on ventilatory drive. Anesthesiology 60:106-110 
4. Kazemi H, Hoop B 1991 Glutamic acid and gamma-aminobutyric acid neurotransmitters in central control of breathing. J Appl Physiol 70:1-7

5. Ang RC, Hoop B, Kazemi H 1992 Role of glutamate as the central neurotransmitter in the hypoxic ventilatory response. J Appl Physiol 72:1480-1487

6. Takala J, Askanazi J, Weissman C, LaSala PA, Milic-Emili J, Elwyn DH. Kinney JM 1988 Changes in respiratory control induced by amino acid infusions. Crit Care Med 16:465-469

7. Kirvela O, Thorpy M, Takala J, Askanazi J, Singer P, Kvetan V 1990 Respiratory and sleep patterns during nocturnal infusions of branched chain amino acids. Acta Anaesthesiol Scand 34:645-648

8. Askanazi J, Weissman C. LaSala P. Charlesworth PM 1983 Nutrients and ventilation. Adv Shock Res 9:69-79

9. Mayfield SR, Uauy R, Albrecht J, Harmon A 1990 Parenteral amino acids (AA) increase minute ventilation $\left(V_{E}\right)$, tidal volume $\left(V_{T}\right)$ and mean inspiratory flow (MIF) in VLBW infants. Pediatr Res 27:286A(abstr)

10. Feldman JL, Smith JC 1989 Cellular mechanisms underlying modulation of breathing pattern in mammals. Ann NY Acad Sci 563:114-128

11. Fernstrom JD, Wurtman RJ 1971 Brain serotonin content: physiological dependence on plasma tryptophan levels. Science 173:149-159

12. Fernstrom JD, Larin F, Wurtman RJ 1973 Correlations between brain tryptophan and plasma neutral amino acid levels following food consumption in rats. Life Sci 13:517-524

13. Armijo JA, Florez J 1974 The influence of increased brain 5-hydroxytryptamine upon the respiratory activity of cats. Neuropharmacology 13:977-986

14. Lundberg DBA, Mueller RA, Breese GR 1980 An evaluation of the mechanism by which serotonergic activation depresses respiration. J Pharmacol Exp Ther 212:397-404

15. Dempsey JA, Olson Jr EB, Skatrud JB 1986 Hormones and neurochemicals in the regulation of breathing. In: Fishman AP. Cherniack NS, Widdicombe JG, Geiger SR (eds) The Respiratory System: Control of Breathing. American Physiological Society, Bethesda, MD, pp 181-221

16. Moss IR, Inman JG 1989 Neurochemicals and respiratory control during development. J Appl Physiol 67:1-13

17. Tashian R 1961 Inhibition of brain glutamic acid decarboxylase by phenylalanine, valine, and leucine derivatives: a suggestion concerning the etiology of the neurological defect in phenylketonuria and branched-chain ketonuria. Metabolism 10:393-401

18. Yamada KA, Hamosh P, Gillis RA 1981 Respiratory depression produced by activation of GABA receptors in hindbrain of cats. J Appl Physiol 51:12781286

19. Hedner T, Hedner J, Bergman B, Iversen K, Jonason J 1983 Effects of GABA and some GABA analogues on respiratory regulation in the preterm rabbit. Biol Neonate 43:134-145

20. Blanco CE, Hanson MA, Johnson P, Rigatto H 1984 Breathing pattern of kittens during hypoxia. J Appl Physiol 56:12-17

21. Grunstein MM, Hazinski TA, Schlueter MA 1981 Respiratory control during hypoxia in newborn rabbits: implied action of endorphins. J Appl Physiol $51: 122-130$

22. Lawson EE, Long WA 1983 Central origin of biphasic breathing pattern during hypoxia in newborns. J Appl Physiol 55:483-488

23. Long WA, Lawson EE 1984 Neurotransmitters and biphasic respiratory response to hypoxia. J Appl Physiol 57:213-222

24. Lister G, Hoffman JIE, Rudolph AM 1974 Oxygen uptake in infants and children: a simple method for measurement. Pediatrics 53:656-662

25. Lin J, Suguihara C, Huang J, Hehre D. Devia C, Bancalari E 1993 The effect of NMDA receptor blockade on the ventilatory response to hypoxia in unanesthetized newborn piglets. Pediatr Res 33:334A(abstr)

26. Huang J, Suguihara C, Hehre D, Lin J, Bancalari E 1992 Effect of a GABA antagonist on the ventilatory response to hypoxia in newborn piglets. Pediatr Res 31:310A(abstr)

27. Millhorn DE, Eldridge FL, Waldrop TG 1980 Prolonged stimulation of respiration by endogenous central serotonin. Respir Physiol 42:171-188

28. Millhorn DE, Eldridge FL, Waldrop TG, Klingler LE 1983 Centrally and peripherally administered 5-HTP have opposite effects on respiration. Brain Res 264:349-354

29. Yoshioka M Goda Y Togashi H Matsumoto M Saito H 1992 Pharmacological characterization of 5 -hydroxytryptomine-induced apnea in the rat. J Pharmacol Exp Ther 260:917-924

30. Schlenker EH, Goldman M 1986 Aspartic acid administered neonatally affect ventilation of male and female rats differently. J Appl Physiol 61:780-784

31. Haji A. Remmers JE. Connelly C. Takeda R 1990 Effects of glycine and GABA on bulbar respiratory neurons of cat. J Neurophysiol 63:955-965

32. Zwillich CW, Sahn SA. Weil JV 1977 Effects of hypermetabolism on ventilation and chemosensitivity. J Clin Invest 60:900-906

33. Rothman D, Udall JN, Pang KY, Kirkham SF, Walker WA 1985 The effect of short term starvation on mucosal barrier function in the newborn rabbit. Pediatr Res 19:727-731

34. Guiraldes E, Hamilton JR 1981 Effect of chronic malnutrition on intestinal structure, epithelial renewal and enzymes in sucking rats. Pediatr Res 15:930934

35. Pierce N, Fedson D, Brigham K. Permutt S, Mondal A 1971 Relation of ventilation during base deficit to acid-base values in blood and spinal fluid. J Appl Physiol 30:677-683 